Misled and Mis-sold: Financial Misbehaviour in Retail Banks?

No. 174

31-Aug-2016

Monika Halan and Renuka Sane

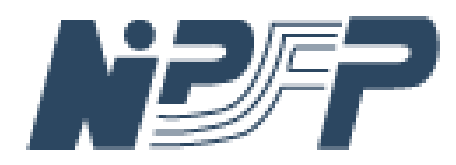

National Institute of Public Finance and Policy New Delhi 


\title{
Misled and Mis-sold: Financial Misbehaviour in Retail Banks?
}

\author{
Monika Halan and Renuka Sane*
}

\begin{abstract}
We use an audit methodology where auditors ask for tax-saving instruments from banks and document the disclosures made on product features at the time of sale. In private sector banks with high sales incentives, the high commission product is recommended. In public sector banks, where there are deposit mobilisation targets, fixed deposits are recommended. Banks rarely make voluntary disclosures on product features. When specifically requested, information provided is inaccurate or incomplete. Our results demonstrate the challenges of mandating disclosures when buyers have little understanding of the relevance of product characteristics, and distributors are themselves ignorant or influenced by incentives.
\end{abstract}

Keywords: Retail Finance, Banks, Consumer-Protection, Disclosure, Sales Incentives, India

JEL Classification codes: D14, D18, G21

\footnotetext{
*Monika Halan is Consulting Editor, Mint, and Consultant with the National Institute of Public Finance and Policy. Corresponding author, Renuka Sane is a visiting faculty at the Indian Statistical Institute, Delhi. We thank the NSE-IFF initiative on household finance for funding. We also thank participants of the NSE-IFF conference on household finance, the ISI Delhi and IIM Bangalore seminar series for useful suggestions. We would also like to thank Joshua Felman for useful comments. We thank Indicus Analytics, a Nielsen company for the audits. All errors are our own. Email: monikahalan@gmail.com, renukas@gmail.com
} 


\section{Introduction}

Easy access to adequate capital, both long and short term, is one of the key drivers of economic growth (Levine, 2005; Bordo and Rousseau, 2012). A crucial part of this process is the conversion of household savings into investment, thereby providing funds for productive business. A large financial intermediation industry has evolved to channel savings into financial assets. The reputation of this industry, however, has suffered many blows for not working in consumerinterest.

The financial sector in the UK, for example, has been witness to several mis-selling episodes in the last three decades: the pensions scandal in the 1980s (recognised by regulators only in 1993-94), the endowment mortgage scandal in mid 1990s, and more recently, the Payment Protection Insurance (PPI) mis-selling episode in early 2000s. This appears to be true even in emerging economies such as India. Halan, Sane, and Thomas (2014) show that investors lost upto US $\$ 28$ billion to mis-selling of unit linked insurance products between 2005 and 2012. Similarly, Anagol and Kim (2012) estimate losses of US $\$ 350$ million from shrouding of fees by Indian mutual funds. A fall out of this is the erosion, not only of financial wealth, but also of trust which can damage participation in financial markets (Guiso, Sapienza, and Zingales, 2008).

Regulators around the world, including countries such as India, have responded by strengthening consumer protection regulations to improve incentive alignment between distributors and consumers and facilitate more informed decision making by consumers. This has taken the form of ban on commissions and volume based payments, suitability requirements in the sale of products and mandatory disclosure requirements. Research on evaluating the impact of these measures is slowly building. Anagol, Marisetty, et al. (2014) find no impact of the ban on mutual fund entry-loads in India on fund flows as funds found other ways of paying commissions. The evidence on the impact of disclosure standards is mixed (Kozup, Howlett, and Pagano, 2008; Loewenstein, Cain, and Sah, 2011; Beshears et al. 2009).

Regulators might require sales staff to disclose product features, but have little control over whether they are actually disclosed, and importantly, disclosed truthfully. Research on the impact of disclosures in retail finance studies whether voluntary disclosures are made, and assumes that when disclosures are made, they are accurate. There is, to our knowledge, not enough evidence on whether agents intentionally or otherwise make mistakes in the disclosures. This can have large consequences, especially in environments such as India, where financial literacy is low, and regulatory enforcement appears weak.

This discussion brings into focus three questions that are the object of the paper. Do intermediaries distribute products that are the highest fee generating without regard to consumer interest? What disclosures do they make on product features? Are these accurate? Theory predicts that intermediaries will sell the most remunerative product, and little information on product features will be voluntarily provided. We conduct an audit of the sales process of retail financial products in banks in Delhi, India. We vary our treatments to include informed and uninformed customers with different amounts to invest. 
We find that managers aren't particularly interested in understanding their customer's requirements. In private sector banks, where remuneration is linked to sales, managers make some effort in understanding auditor goals, but recommend the highest-fee paying product (a life insurance policy). In public sector banks, where there are no such pecuniary incentives but there are deposit mobilisation targets, managers do not make any effort in understanding the auditors and only recommend fixed deposits. This suggests a market with two extremes. The private sector prescribes the most expensive products, while the public sector prescribes the least effort default product. In either case, unbiased financial advice in the interest of the customer seems to be missing. This is reminiscent of the situation of health care in India - where the private sector makes more of an effort and prescribes more drugs (often to the detriment of the patient), while the public sector does less of both (Das and Hammer, 2007).

Regardless of the bank, or the product sold, bank managers rarely disclose complex product attributes such as costs and lock-in. When pressed for information on these features, managers provide information, but in a majority of the cases, the content of the disclosure is incorrect, or incomplete. It is possible that bank managers themselves do not know the product features to be able to disclose them correctly, or that they perceive that customers are impatient and do not want to listen. However, if regulations require the managers to make disclosures, then their own ignorance, or inability to engage with an impatient customer require regulatory attention.

Our results are sobering in the context of the recent financial inclusion efforts underway in India. These include the Jan Dhan Yojana launched in 2014 which has created 1.9 billion new bank accounts with Rs 269 billion in deposits (DFS, 2014). In addition, there is a move to distribute pensions and insurance products through the banking channel. For example, the two insurance programs, Suraksha Bima Yojana (DFS, 2015b) and Jeevan Jyoti Bima Yojana (DFS, 2015c) that are distributed through the banking channel have led to the purchase of 92 million and 29 million policies respectively. ${ }^{1}$ The government also launched a co-contribution pension scheme, the Atal Pension Yojana in 2015 that is also being distributed through the banks (DFS, 2015a). We show that the sale of financial products through banks requires more policy attention. Instead of improving access to finance, a bank led sales strategy may result in driving customers further away from it.

This is the first paper to our knowledge to conduct an audit study on the sale of products through the banking channel to Indian urban middle-class investors, as well as on the kinds and veracity of disclosures made. The work in this study connects up to a small emerging literature on household finance, and particularly the problems of consumer protection in India as well as the world (Campbell et. al., 2011; Mullainathan, Noeth, and Schoar, 2012; Beyer, Meza, and Reyniers, 2013; Gine, Cuellar, and Mazer, 2014). It also connects to the literature on the limitations of competition and difficulties of regulation in markets where buyers are so unaware that they cannot reason about relevant facts (Milgrom, 2008).

\footnotetext{
${ }^{1}$ It will take another few years to see the claims history to conclude if these have actually provided the insurance cover that was promised.
} 


\section{Research Setting}

Understanding the market for retail financial advice has become an important field over the last decade. The consensus of the research seems to be that even in environments with high competition, financial institutions sell products by shrouding prices, and deceiving customers (Gabaix and Laibson, 2006; Heidhues, Koszegi, and Murooka, 2014). Moreover, research finds limited voluntary disclosures when number of customers who could actually understand the disclosures is likely to be low (Fishman and Hagerty, 2003), and policy initiatives to increase transparency get undermined (Duarte and Hastings, 2012).

There has also been an emergence of the use of audit methodology to gather evidence on the market for financial advice. In more developed economies it has focused on evaluating advisor behaviour (Mullainathan, Noeth, and Schoar, 2012), while in emerging economies, it has focused on agents specifically in one sector such as insurance (Anagol, Cole, and Sarkar, 2012) or on low income customers (Gine, Cuellar, and Mazer, 2014; Mowl and Boudot, 2014). The evidence suggests that financial intermediaries reinforce biases of investors that are in their own interests, overwhelmingly recommend products which provide high commissions to the agent and are unsuitable for customers and seem to rarely voluntarily provide information on product features such as fees that can have an adverse impact on overall portfolio outcomes. While research has provided us with some evidence on whether agents make voluntary disclosures, little is known on the veracity of those disclosures.

We turn our attention to middle-income urban customers in a large emerging economy, India, and focus specifically on the banking sector. This is a unique setting because of the co-existence of a public and private banks with different ways of functioning, as well as regulatory arbitrage between multiple regulators in the financial landscape owing to product based regulation. We test whether bank-based advisors give advice that furthers their own interest at the cost of the customer, and whether managers make disclosures at the time of sale, especially when such disclosures are required by regulation. More importantly we test whether advisors make correct disclosures at the time of sale. Our research questions are as follows:

1. What products do bank based managers recommend? How does this vary when the auditor makes a specific request vs. when the auditor appears uncertain? Are auditors who make specific requests, and are more certain of their requirements able to purchase the product of their choice?

2. What product features get disclosed? Do the more salient attributes of a product, such as returns, get disclosed more frequently, while complex product features such as costs, or charges on early exit get shrouded?

3. Are these disclosures accurate?

4. What might the drivers of product recommendations be? When remuneration is tied to sales-linked bonuses, are the most expensive products sold? 
In Section 2.1 we make a case for bank based advisors as the choice for the experiment by describing the emergence of banks as a distributor of retail financial products and the growing importance of the banking sector in improving access to finance. In Section 2.2 we describe the differential commissions in the sale of similar financial products that come under different regulators in India, and the incentives they create for the sale of financial products. In Section 2.3 we show that while there might be differences in the commissions of financial products, regulators do make demands on disclosures on product sales.

\subsection{The role of banks}

The Indian financial sector, prior to privatisation in the 1990s, consisted primarily of state owned banks, the state owned life insurance monopoly and a state owned mutual fund company. The state owned insurance and mutual fund companies had their own armies of agents that sold products to households. Once mutual funds and then insurance were opened up to the private sector, the new companies found it difficult and expensive to build their own agency force. Given the ready access of banks to people's deposits, the idea of using banks as a sales channel by the insurance companies took root (Joshi and Pandya, 2003).

Third party distribution of financial products turned into a big business opportunity for banks. In 2014-15, of the top ten mutual fund distributors on the basis of commissions earned, six were banks. In the case of insurance as well, banks had the largest share of new business premium, especially for private insurance companies (Barbora and Vishwanathan, 2016). From the banks perspective, commissions from sale of third-party products contribute substantially to bank profitability (Balaji and Bhaskaran, 2015). Banks have, thus, become an important channel for the distribution of financial products.

Once banks started selling third party financial products that were designed under the regulatory oversight of other financial regulators, instances of mis-selling began to come to light. $^{2}$. The Indian media and consumer protection groups have been raising this issue for the last half decade. ${ }^{3} \mathrm{~A}$ committee formed by the insurance regulator on the sale of insurance products through banks has also admitted to mis-selling through banks (IRDA, 2011).

While regulators have begun to take notice of the problem of mis-selling by banks (Saraswathy, 2015; Halan, 2015), this has, however, not resulted in any publicly disclosed regulatory investigation, and enforcement. In the initial years, it appeared that consumer distress arising from third party sales through bank branches was not a priority for the RBI. But recently, the $\mathrm{RBI}$ has asked banks to put in place a board approved policy that guarantees six basic rights of customers. ${ }^{4}$ These rights are across financial products and two rights in particular are pertinent in the context of this study. These include the right to transparency,

\footnotetext{
${ }^{2}$ Regulation in India is designed in silos related to products. The Insurance Regulatory Development Authority of India (IRDAI) is the insurance regulator, the Securities Exchange Board of India (SEBI) is the capital markets regulator, the Reserve Bank of India (RBI) is the banking regulator, the Pension Fund Regulatory and Development Authority (PFRDA) is the pensions regulator.

${ }^{3}$ For example see (Datta-Ray, 2015) and (Basu, 2015) for recent commentary on mis-selling in banks.

${ }^{4}$ SS2016 Manufacturing Sector 10-08-16.docx
} 
fair and honest dealing that mandates that the deal is transparent and fair. The second is the right to suitability which mandates an assessment of the customer to gauge his financial circumstances and understanding. These rights were operational at the time of the study. Action by banks on these is not yet manifest.

Even though anecdotal evidence on mis-selling is building up, consumers in India place a high trust on banks. A 2013 Gallup Poll showed that 70 percent of the Indians polled said they trusted banks. The answer was 13 percent for Greece, 27 percent for the UK and 37 percent for the USA. ${ }^{5}$ Banks, when they discharge their basic function, that of holding money safe and giving a small return on deposits are trusted as instances of large public and private sector banks going bankrupt and hurting depositors are unheard of in India. It is this trust in the basic banking function that is carried over when buying third party products such as mutual funds and insurance.

The role of banks becomes important as there is a renewed emphasis on increasing financial access through banks. As described earlier, the government has also begun offering pension and insurance products through these bank accounts to make financial products more accessible to the excluded Indians. As this pipeline for the sale of financial products is being built, the need for understanding current bank behaviour in selling third party products becomes even more important. It would be harmful to the goal of financialisation of the economy to allow pipelines to reach the most vulnerable, if they do not work in consumer interest.

\subsection{Distributor incentives}

We turn next to the environment of sales incentives that banks and other distributors operate in. In India, financial sector regulation is product specific. This means that financial products get regulated by different regulators, all of whom operate in silos. For example, the Securities Exchange Board of India (SEBI) is the capital markets regulator, while the Insurance Regulatory Development Authority of India (IRDAI) is the insurance regulator. Very often, this means that similar products have different caps on permissible commissions and other benefits ${ }^{6}$ because technically they come under different regulatory regimes. Distributors, thus face an environment with much skewed incentive structures for the sale of similar financial products.

Academic research has shown that when commissions differ, agents overwhelmingly sell the product that has the highest rewards for them. ${ }^{7}$ Evidence in India also points to a similar result. Anagol and Kim (2012) have found that for a brief period in 2006, when commissions on closed-end mutual funds were higher than on open-ended funds, inflows into the more expensive funds were much higher, and that investors paid approximately US $\$ 500$ million in extra fees in this period.

This issue was raised by a Committee set up by the Ministry of Finance to recommend measures for curbing mis-selling and rationalising distribution incentives in

\footnotetext{
${ }^{5}$ Retrieved from http://goo.gl/5rXMLE

${ }^{6}$ These could range from gifts of television sets and iPADs, to holidays in exotic locations.

${ }^{7}$ White House (2015) provides a review of international academic studies.
} 
financial products (DEA, 2015). Table 1, first described in the Committee Report, shows the first year commission as a percent of total commission earned by the distributors on the sale of a mutual fund (regulated by the securities market regulator), a unit linked insurance plan and a traditional life insurance endowment plan (both regulated by the insurance regulator). The insurance plans are largely investment products with some insurance embedded in them.

In case of 15 year tenure, distributors in mutual funds would earn only 1.11 percent of total commissions as upfront commission, in comparison with endowment insurance plans, where distributors could earn almost 26 percent of total commissions as upfront commissions. In case of ULIPs as well the commissions are front loaded with year 1 commissions at about 22 percent. The front loading of commissions in insurance becomes even more acute for product with a ten year or lower tenure.

There are large differences in commissions from the sale of products, especially in the year of the sale. If remuneration of agents is linked to sales targets, and if fee income constitutes a large part of profits, the gains to the bank from selling the high-commission products can be significant.

Table 1: Misalignment: Front loaded commissions

\begin{tabular}{|c|c|c|c|}
\hline $\begin{array}{l}\text { Tenure } \\
\text { (in Years) }\end{array}$ & $\begin{array}{c}\text { Mutual fund } \\
\text { (Hybrid scheme) }\end{array}$ & ULIP & $\begin{array}{l}\text { Insurance plans } \\
\text { Traditional plans }\end{array}$ \\
\hline 30 & $0.17 \%$ & $12.0 \%$ & $15.0 \%$ \\
\hline $\begin{array}{l}25 \\
20 \\
15 \\
10 \\
5\end{array}$ & $\begin{array}{l}0.30 \% \\
0.54 \% \\
1.11 \% \\
2.79 \% \\
11.0 \%\end{array}$ & $\begin{array}{l}14.0 \% \\
17.0 \% \\
22.0 \% \\
31.0 \% \\
50.0 \%\end{array}$ & $\begin{array}{l}17.0 \% \\
21.0 \% \\
26.0 \% \\
36.0 \% \\
56.0 \%\end{array}$ \\
\hline
\end{tabular}

Note: Annualised net return on investment for a consumer is assumed at $8 \%$.

Source: (DEA, 2015)

This table shows the first year commissions as a percent of total commissions earned. MF Commission: Zero upfront, Year 1 Trail: $1.00 \%$, Year 2 onwards: $0.50 \%$ on AUM. The commissions for comparison purpose are taken for a hybrid fund and not for a pure equity fund as both unit linked insurance plans (ULIPS) and traditional insurance plans have debt and equity. Long term trail on hybrid funds range from $0.20 \%$ to $0.50 \%$. ULIP Commission: Year $1: 8 \%$ on premium (While the commission caps are same as traditional plans, $8 \%$ is taken based on industry average of 7-9\%), Year 2 onwards at $2 \%$ while the cap is $7.5 \%$ for year 2 and 3 and goes down to $5 \%$ year 4 onwards. Traditional Insurance Plan: Year 1: $35 \%$ of premium (While the commissions are capped at 35\%, $25 \%$ is taken as a more representative number), Year 2 onwards $5 \%$ (while the cap is $7.5 \%$ of premium for Year 2 and 3 and is $5 \%$ of premium for year 4 and beyond. Based on the above assumptions, a distributor selling a 15 year traditional plan could earn in Year 1, up to $26 \%$ of the total commission he could earn over the policy tenure. In case of a ULIP this would be $22 \%$ of the total commission in year 1 even though overall commissions over 15 years would be less than mutual fund. However, a mutual fund distributor would only earn $1.11 \%$ of the total commissions in Year 1.

\subsection{Regulatory requirements on disclosures}

While the regulatory environment has led to differences in permissible commissions, the differences in disclosure requirements are lower. The insurance regulator, the IRDAI, 
protects investor interest through the Protection of Policyholders' Interest Regulation 2002 (IRDA, 2002). The regulations mandate that insurance distributors must advise the prospect dispassionately. This regulation puts the onus of spelling out the benefits, extent of the insurance cover onto the manufacturer and has guidelines on what has to be put in the brochure. The regulations also say that, "an insurer or its agent or other intermediary shall provide all material information in respect of a proposed cover to the prospect to enable the prospect to decide on the best cover that would be in his or her interest."

The capital markets regulator, SEBI, protects the investor through regulations that apply to the Asset Management Companies (AMCs) in ensuring that they appoint distributors who are able to assess product suitability. In addition to this the mutual funds industry association, AMFI, has a code of conduct for mutual fund intermediaries. SEBI mandates that all distributors must follow the AMFI Code of Conduct (SEBI, 2014). In addition, through a Gazette Notification dated December 11, 2012, SEBI has brought misselling of Mutual Fund Schemes under the ambit of Fraudulent and Unfair Trade Practices. Mis-selling is defined as sale of units of a Mutual Fund Scheme by any person, directly or indirectly by a) making a false or misleading statement, b) concealing or omitting material facts of the scheme, c) concealing the associated risk factors of the scheme, or d) not taking reasonable care to ensure suitability of the scheme to the buyer.

Bank managers, as distributors of financial products, should comply with the regulations on the sale of the products. In fact, the Master Circular on para-banking activities of the RBI advises banks to disclose to their customers, details of all the commissions/other fees (in any form) received, if any, from the various mutual fund/insurance/other financial services companies for marketing/referring their products (RBI, 2015). The Charter of Consumer rights by the $\mathrm{RBI}$ also states that the product's price, the associated risks, the terms and conditions that govern the use over the product's life cycle and the responsibilities of the customer and the financial services provider should be clearly disclosed

All of this suggests we should generally expect complete and honest disclosures from the banking staff when recommending retail financial products.

\section{Experimental design}

Our starting point is a customer looking for a tax-saving product. Over the past decades, tax-saving financial products have become a mainstay of the financial portfolio of middle- class India. As a result, a tax-saving product is often the entry point of financial sector investment for most middle class Indians. One is more likely to find a customer walk into a bank looking to buy a tax-saving product rather than a retirement product or a stock market product. This motivates our setting. Also, a design of tax-based products narrows the universe of possible product choices, allowing us to evaluate the response of the bank manager.

The tax advantaged products are listed in Section $80 \mathrm{C}$ of the Income Tax Code. ${ }^{8}$ The

\footnotetext{
${ }^{8}$ The full list is here: http://goo.gl/SJyOz9
} 
more popular products include:

a) Notified fixed deposits: These are five year term deposits held by banks where the interest rate is guaranteed.

b) Small savings schemes: These include the Public Provident Fund and the National Savings Certificates which are managed by the Government of India and also provide a guaranteed rate of return.

c) Equity linked savings schemes (ELSS): These are provided by asset management companies and invested in the market across asset classes, and thus provide a market linked return.

d) Insurance schemes: There are two kinds of insurance products sold. Pure insurance products (i.e. term insurance) are those that do not have an investment component, while the second category is that of insurance bundled with investments. Within the class of bundled products, there are two kinds. The first are the "traditional endowment products" which invest largely in government bonds and are not linked to market returns. Some endowment products are "participating plans" which offer a share in profits of the company, but these are typically not made in stock market products. Non-participating plans typically provide a guaranteed benefit when the policy term completes, and the customer does not share in the profits of the company. The second are the "unit-linked insurance plans" which are market-linked across asset classes. All the insurance products are manufactured by insurance companies.

Some basic features of the better known and used investment products are provided in Figure A.1 in the appendix.

\subsection{Treatments}

We vary the product request: in some cases the customer is an informed customer who requests for a specific product. In our case this is the ELSS, which is an open-ended diversified equity mutual fund with a three year lock-in. The ELSS reflects a certain sophistication in product evaluation based on past returns, low costs, and a shorter lock- in, and is therefore the product of choice of the informed customer. ${ }^{9}$ In other cases, the customer is uninformed, and displays a need for a tax-saving product without a definite preference for any product.

We also vary the amount available for investment. In some cases the request is for investing Rs 25,000 in either the ELSS or a tax-saving product. In other cases the amount to be invested is Rs 100,000. The average annual retail investor investment amount in a mutual fund is Rs 61,000 while the average ticket size that of a life insurance investment is $R s 46,000 .^{10}$ The amounts of Rs 25,000 and Rs 100,000 are in range of the average ticket size of investments in mutual funds and insurance.

We, thus, have the following four scenarios each played out in a public sector and a private sector bank branch.

- Rs 25,000 amount in ELSS

- Rs 25,000 in some tax instrument

- Rs 100,000 amount in ELSS

9 We describe the reasons for choosing the ELSS in greater detail in Section 3.2.

10 AMFI (2015) and IRDAI (2014) 
- Rs 100,000 in some tax instrument

In an ideal scenario, bank managers will sell ${ }^{11}$ the product requested by the customer (in the case of the ELSS) either because it is a sound investment or because they are merely acting as distributors of the product and not as financial advisors. In the case where customers do not have a view on the product, the bank managers should make an effort to sell the more suitable product, or at the very least show all possible products so that the customer can make an informed choice. If, on the other hand, bank based advisors are not working in the interest of the customer, they will try to steer both types of customers towards the product that maximises their incentives, whether it is fee maximisation or deposit targets.

\subsection{Why ELSS?}

An ELSS is an open-ended diversified equity mutual fund with a three year lock-in. Investors cannot withdraw the money before three years, but once the lock-in is over, they can continue holding the product. Subsequent investments into the same fund in the next year will get the tax benefit for the next year. ELSS product features vis-a-vis the other products are described as follows:

Returns The four products that a bank offers in the $80 \mathrm{C}$ bucket are five-year tax-saver deposits, Public Provident Fund, life insurance policies AND ELSS. The ELSS offers the best returns in this basket of products as detailed below (as of June 2015):

\begin{tabular}{lccc}
\hline Product & $\mathbf{5}$ years & $\mathbf{1 0}$ years & $\mathbf{1 5}$ years \\
\hline FDs & $7.5 \%$ & $7 \%$ & $\mathrm{NA} \%$ \\
PPF & $\mathrm{NA}$ & $\mathrm{NA}$ & $8.70 \%$ \\
ULIP & $11.77 \%$ & $16.36 \%$ & $\mathrm{NA} \%$ \\
Traditional insurance plans & negative & $3-6 \%$ & $3-6 \%$ \\
ELSS & $14.32 \%$ & $17.17 \%$ & $15.46 \%$ \\
\hline
\end{tabular}

Note: In 2016 FDs returns have dropped to 7\% while PPF has fallen to $8.1 \%$

Source: Morningstar database, and industry estimates

The ELSS category of funds has given an average annual return of 12.67 percent over the last 10 years. While it is true that ELSS is market-linked, there is a case to be made for sophisticated investors to choose ELSS for tax saving over bank deposits, insurance policies and other guaranteed products. For instance, a tax- deductible 5 year bank deposit has no costs and comes with a guaranteed return of 8 percent12, but gives a negative real return when inflation rates are high, as has been the case in India. Once the interest income tax impact is built in, the returns are negative (for investors in high tax slabs) even if post inflation, the FD gives a positive real return.

\footnotetext{
${ }^{11}$ In these experiments sell implies a verbal recommendation, and the start of the paperwork for actual investment.

${ }^{12}$ This has recently fallen and is 7 percent as of July 2016
} 
Costs: In any financial product, what matters are not just costs of investment, but also costs of on-boarding, fund management, early surrender and exit. Table B.4 in the Appendix shows the difference in costs of mutual funds and insurance products in greater detail.

a) Costs at the time of investment: The FD, PPF and mutual funds (ELSS) have no costs to the investor for investing in the product. The entire amount is invested and there are no charges in the form of commissions. This means that all of the money, say Rs 1000 , gets invested and nothing is deducted towards a sales commission upfront.

In the case of mutual funds, a transaction charge is allowed for investors in- vesting more than Rs 10,000 and Rs 150 for first time investors investing more than Rs 10,000. Mutual fund agents are paid up to 1 percent of the investment by asset management companies by upfronting their trail commissions or by dipping into their capital.

In the case of Unit linked Insurance Products (ULIPs), the industry standard on commissions charged to the investor has settled at between 7-9 percent of the first premium (DEA, 2015). This is money deducted from the investment before it gets invested. For traditional products, upfront commissions are linked to the tenor of the policy. Policies of tenor less than five years have a maximum commission of 15 percent. Those between five and 12 years have a graded grid of increasing commissions. Policies with a tenor of more than 12 years have a maximum commission cap of 40 percent for companies that have been in existence for less than 10 years and 35 percent for those in existence for more than 10 years. Recent draft regulations by the IRDAI suggest taking commissions and market value of other benefits to these up to a peak rate of 70 percent (IRDAI, 2016). The gains to the distributor from such differential commissions at the time of investment have been described in Table 1 in Section 2.2.

b) On-going cost:The ongoing costs of FD and PPF are zero. The expense ratio of a mutual fund that is capped at 2.5 percent for an equity fund collapses all the costs into this number. All trail commissions come from this expense ratio. The ongoing costs of a ULIP and ELSS are comparable with an annual cost of between 1.5 percent and 2.5 percent. Traditional policies have no limits on what they can charge the investor in terms of on-going costs.

c) Costs of early redemption: The costs of early redemption are two. One, in losing the tax deduction if redeemed earlier than the prescribed lock in. Two, costs in terms of what the manufacturer can deduct as surrender charges. Early redemption of a 5-year FD will lose the tax benefit and reduce returns by half a percentage point. PPF is a locked product and early withdrawal is not allowed. ULIPs have a 5-year lock in. If surrendered before that, a maximum charge of Rs 6,000 is levied.

ELSS have a three year lock in and redemption before three years is not al- lowed. Traditional policies do not have a lock in but policyholders lose the tax benefit if they lapse the policy after two years for policies with a tenure of 10 years or less, and for 
longer term plans, this is three years. Polices lapsed in the first two years have 100 percent costs deducted. Polices that are sur- rendered after that could return between 30-40 percent of premiums paid till year four.

Transparency: A product is transparent if its costs and benefits are clearly visible and understood by the investor. FD and PPF returns are easy to understand and are linked to a percentage return on the invested amount. ULIP and ELSS returns are market linked and are showcased as a percentage return on the invested amount. However, in ULIPs all costs are not accounted for in the 'net asset value' number since the front end commissions are excluded from the computation of the NAV as are mortality and policy administration costs (which are deducted by unit cancellation). This overstates the returns in the disclosure. The ELSS NAV accounts for all the costs and is easily comparable across the various ELSS products in the market. Traditional plans in insurance are opaque and the costs and benefits are not clearly obvious. Returns are not given in average annual rates of return, but in multiples or percentages of the premium or the sum assured.

Portability: For closed end market linked products, portability or the ability to move money from a poor asset manager to a better one is very important. The participating traditional insurance plan and the ULIP are not portable, post the lock-in, forcing the investor to stay on in the product even if returns are poor. This is the same in case of a fixed deposit, where an investor cannot port to another higher paying FD. The ELSS, post a 3 year lock in, is portable to any other mutual fund IN the market.

A criticism against the ELSS as the choice of the "sophisticated" investor is that it is a market linked product, and it is likely that for many investors a guaranteed product such as a fixed deposit or an insurance plan is more appropriate. While there is merit in this argument, our evaluation of product recommendations does not really rely on the ELSS being the optimal product. If bank managers feel that the ELSS is not the most suitable product, then we should see this in the conversations they have with the auditors, as well as the recommendations they finally make. The focus of the experiment is not so much about which is the better product, but about the process in which a product is sold.

\subsection{Product features and their disclosures}

Not only is the product recommended important, but also the disclosures of product features, especially given the regulatory requirements around them. We believe, there are five areas of information that must be disclosed accurately, such that an average consumer can take effective decisions. These are:

Returns: This is the most important attribute that incentivises a person to defer consumption. Investors typically want returns to be as large as possible, other things being equal. The way returns are presented makes a difference in the person going ahead or not with the investment (Shaton, 2014). We, therefore, need to pay attention to how returns are disclosed. For instance, a product that requires it to be held over the long term (at least 5 to 7 years), must have a return disclosure that mandates an average annual past return disclosure across that period. Showing the "best" return rate regardless of the holding period, or the most 
recent return would be misleading.

Risk and volatility: While return is the most obvious attribute of a financial product, risk and volatility are also key determinants in the investment decision. Typically investors shy away from risk to the capital, though the concept of taking on structured risk in a systematic manner is being understood slowly in India.

Disclosure on risk must be broader than the risk of volatility. It must include the risk of loss of purchasing power due to inflation, the risk of high costs eating into future returns and the risk of absence of liquidity and high transactions costs. In the Indian context, a guaranteed return is very important to the investor, therefore the disclosure of the guarantee and its quantum is important.

Costs: Costs should be an important part of the investment decision because they reduce returns. A product that costs an annual charge of 3 percent on the assets under management and another that costs 2.5 percent, will make a difference of about 10 percentage points over a 20 year period in the final corpus at the same rate of return.

Disclosure on costs must be such that the seller does not shop for the most favourable cost in the product and only discloses the one that is convenient. For example, mutual funds in India have no entry loads, but do have an annual expense ratio. Disclosure on cost in a mutual fund must include the annual cost, along with the disclosure of a zero upfront charge. In the insurance product since there are costs under various heads, a full disclosure would need a detailed disclosure statement on all costs and not just the lowest cost amongst all the costs.

Early exit: Ease of entry and exit are also attributes of a good financial product. Open- ended products face exit loads and disclosure of these is important. Particularly important are disclosures on the impact of an early exit on a closed-end product. Certain insuranceproducts in India have rules that allow appropriation of the entire investment by the insurance company if the investor stops the policy within a specified period. Disclosure on the impact of such actions is very important.

Optimal holding period: For how long a product be held is another key part of the sales process. A short-term debt fund is not the product one buys to target a retirement corpus that is 20 year away. Neither does one use a sector fund to target a down payment for a home loan that is less than two years away. Some products cook slowly over time, others are ready to use in a short time.

Managers should ideally be providing disclosures on all the product features. At the very least, the disclosures made must match the information provided on product brochures.

\subsection{Audit logistics}

To implement the audits, we hired a market survey research firm that specialises in primary data collection. The survey agency hired the auditors who included 6 males and 1 
female in the 28-45 age group. ${ }^{13}$ The annual income of the auditors ranged from Rs 500,000 to Rs $2,500,000$. All of the auditors were graduates, while some of them also had a postgraduate degree. Five of the auditors were married, and four of them had children.

All the auditors were trained by us. This included training on basic financial concepts, on the plethora of tax-savings products available in the market, and on how to ask for advice in the bank. In the second round, where auditors specifically ask about product attributes, we trained the auditors to understand what each attribute means, so that the questions sound credible.

The study was double blind; neither the auditors, nor the bank managers knew the true motivation behind the study, or the choice of questions. Our hypothesis is that banks maximise own income rather than serve the customer interest. The auditors were not told that we were testing this hypothesis as this may have incentivised them to intentionally capture mis-selling. They were told that we are testing the process through which banks sell financial products.

There were no fixed appointments made with the banks - auditors just walked in to the banks and asked to see the manager. We designed basic scripts that advisors will narrate once they met the bank manager. Since the audits were at bank branches, it was likely that managers would ask if auditors had accounts in the banks. We trained auditors to respond to this question by suggesting that they were looking to open bank accounts specifically for investment purpose. Depending on the treatment assignment, the auditor would either ask for an ELSS, or for some tax saving product. Auditors were told to truthfully answer all other socio-demographic information such as age, occupation, annual income, marital status, number of children.

Logistics of implementing and monitoring of the visits, filing up of the exit form, as well as compensating the auditors were provided by the audit firm. The exit survey (also designed by us) included questions on a) procedure of suggesting products b) the product finally suggested and c) information about the product that was suggested. The auditors were required to fill the form immediately after each visit.

Each auditor was also required to bring back the visiting card of the bank manager, brochures of products that were suggested, as well as any illustrations made by the manager in explaining the product. Auditors were encouraged to write down the advice given to them, as well as qualitative observations about the bank manager response at the end of each form. We compared these illustrations with the entries filled in the exit form by the auditor to check for consistency. We also conducted exit interviews with auditors after the first round to understand their experience at the banks, and to verify that they had actually gone through the experience themselves.

We chose two time periods to run the audit. The first was in March 2015 because February and March of every year are the periods when tax-saving investments are made. Both mutual funds and life insurance companies roll out their new products and push high volume sales and advertising pitches in these months to sell their products to tax shelter seeking

\footnotetext{
${ }^{13}$ We had to drop the female auditor in the second round of the survey. Female auditors were very difficult to find for a financial product. The lone woman on the team left due to personal reasons
} 
taxpayers. The second period was July, when the big sales push was over and this is the time that a more sophisticated investor would try and start early in his tax saving exercise and look for products.

\subsection{Sampling}

As of March 2009, there were a total of 2,177 bank branches in Delhi. ${ }^{14}$ These can be further stratified as follows: 1,668 branches of public sector banks, 464 branches of (Indian) private sector banks and 45 branches of foreign banks. In this study we focus on the Indian public and private sector banks, though we did include foreign banks. This gives us a sampling frame of 2,132 bank branches.

We conducted a total of 400 audits spread equally over two time periods. The first was in March 2015, and the second in July 2015. Delhi is divided in five administrative zones, and our sampling was stratified along the same lines. We listed bank branches in each zone, and randomly chose the branches that our auditors would visit.

In the first round, our sample was drawn in proportion to the number of public and private sector branches. In round 2, we over-sampled private sector banks, as well as the larger public sector banks, as these were the more important banks from an access to finance perspective. Table B.1 in the Appendix shows the spread of branches we covered by region, as well as ownership.

In Table B.2 in the Appendix we show the distribution across the treatments. This includes the choice of instrument as well as the amount to be invested. Within each type of bank, we have a similar number of visits for each treatment combination.

The visits have been carried out by seven auditors in total. Table B.3 in the Appendix shows the randomisation of the auditors between the treatments, and between private and public sector banks. We find that all auditors have gone through with all the treatments, and have also been to both public and private sector banks.

\section{Results}

\subsection{Did the managers ask for information from auditors?}

One of the pre-requisites for a distributor of a financial product is to collect the information regarding the financial situation of the client before he sells a product. This would include information on marital status, number of dependents, investment goal and horizon and risk appetite and capacity. We found that managers did not make attempts to get more details about the client. The bank managers were first interested in knowing whether the auditor had an account with the bank. Since our auditors did not have an account and the manager

${ }^{14}$ Table 8, Branch Bank Statistics, Reserve Bank of India, 2010. 
could not retrieve details from the system, we would have expected the manager to spend more time asking for personal and situational details from the client, but this was not so. Not having an account with the bank was also not a show-stopper for the conversation to go further, except in foreign banks which refused to entertain our auditors.

Fifty-nine percent of managers asked questions on overall goals of investment. The answer to this question was (by design) that the goal was tax-saving. We expected that the manager should also have asked if the auditor had previously invested in any tax-saving product. More than half the banks, 59 percent, did ask auditors if they had already invested in other tax-savings products previously. However, these questions were not followed up with what the products were, and how much was already invested in such products. Overall, we see that managers don't really make an effort to understand the client.

We ask next if the manager responses vary by auditor characteristics. In Table 2, we regress a dummy indicating whether the bank manager asked any question regarding the auditor's investment requirements on the income and age of the auditor, and whether the bank was a public sector bank. We restrict ourselves to these variables as they are more likely to be observable at the outset. How old an auditor looks, and how well-off he looks is more likely to make an impression on the manager, even if he does not have actual facts about the income and the age. The dependent variable is coded as 1 if the auditor was asked either about overall goals or about his earlier tax savings, and 0 otherwise.

In Column (1), we find that auditors with higher income were asked these questions more often, though the coefficient is close to zero and difficult to interpret.15 When we control for whether the bank is a public sector bank (in Column (2)), we find that the coefficient is negative and statistically significant. This suggests that managers in public sector banks are less proactive in understanding the client and exert less effort.

Table 2: Initial Inquiries by the Bank Manager

Dependent variable:

(1)

Auditor income

Age

Public sector bank

Observations

$\mathrm{R} 2$

F Statistic

Note:

Note:

Made any inquiry

0.00000

(0.00000)

$-0.008$

(0.005)

378

0.088

4.436 *** $(\mathrm{df}=8$;

Regression controls for zone, month of visit and time of visit.
(2)

0.00000

$(0.00000)$

$-0.003$

$(0.005)$

$-0.520^{* * *}$

(0.046)

378

0.325

$* * \mathrm{p}<0.05 ; * * * \mathrm{p}<0.01$

\footnotetext{
${ }^{15}$ It is also statistically significant at the $10 \%$ level.
} 


\subsection{Did managers distribute the requested product?}

It is possible that when a manager is just a distributor of a product, there is no interest in understanding the client. The manager is like a pharmacist, selling what the client demands. If this were the case, we should see that when the auditors made a specific request for an ELSS product, the manager should have complied.

We find that of those who requested an ELSS product, only 14 percent were encouraged to buy it. Thirty percent were actively discouraged, and 55 percent were presented with a neutral response. However, in 71 percent of the cases where the bank manager was neutral to the ELSS product in the beginning, our auditors later noted that the manager steered the conversation to other products, resulting in a product recommendation different from the ELSS. This is at complete odds with the description of a bank manager as a vendor of financial product, and suggests that managers invariably do provide "advice".

Table 3 shows the results from a regression of whether the auditor was steered away from ELSS. The variables include the amount the auditor wanted to invest, whether the bank had a tie-up with a third party services provider, and whether the bank manager claimed to not know what the ELSS was. We also control for the gender of the manager, and the month in which the audit took place - the base for this is the audit that took place in March, just before tax season.

We find two statistically significant reasons why the auditor was steered away. The most important seems to bethe month in which the audit took place. If the audit was in the season just before the deadline for making tax savings then the manager was more likely to steer the customer towards other products relative to when the audit occurred in July (after the tax saving season). It might be that targets on sales of certain products are higher than on ELSS, and the managers are just responding accordingly.

The second variable influencing steering away from ELSS is the knowledge of the manager. In the data-set 10 percent claimed to not know what an ELSS was. 55 percent of the managers claimed to not have the ELSS on their product shelf. In this case, the optimal response as a distributor of a financial product should have been to close the transaction, and suggest that the customer look elsewhere. However, as we have seen earlier, this was not the case. Managers made active recommendations of the products that were available with them, without really understanding the customer's situation.

A third reason could be that managers genuinely think that the ELSS is not the right productfor the customer. In this case managers should have madean effortto understand why the customer wanted an ELSS and then made a case for the customer to change his mind. We know that the managers did not make any effort to understand the customer. They did provide reasons for why the auditor should not invest in the ELSS. Figure 1 shows that managers conveyed that the requested product, the ELSS, was a risky product.

The managers seem to be overly concerned about our auditors having to deal with risk in their portfolio. This may be a valid concern, but it should then be followed by a product recommendation that provides a guaranteed rate of return, and a disclosure that there was a possibility that market risk mitigation came at the cost negative real returns. Both these are not borne out by the data. A large proportion (almost 60\%) actually ULIPs, which are also 
market linked plans making the "riskiness" of the ELSS moot.16 The costs of inflation were never explained.

Table 3: Regression (Steered away from ELSS)

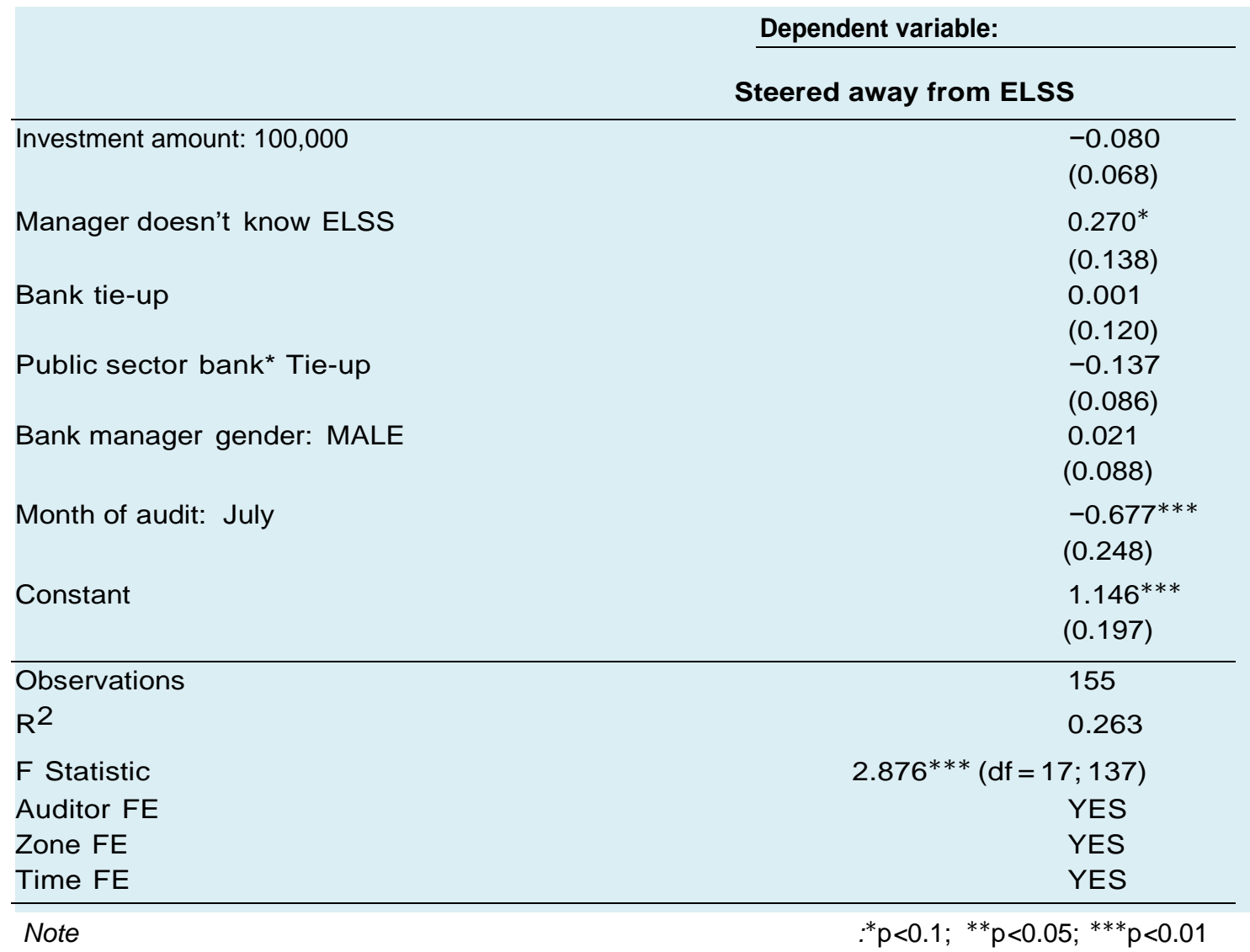

Figure 1: Why steered away from the ELSS?

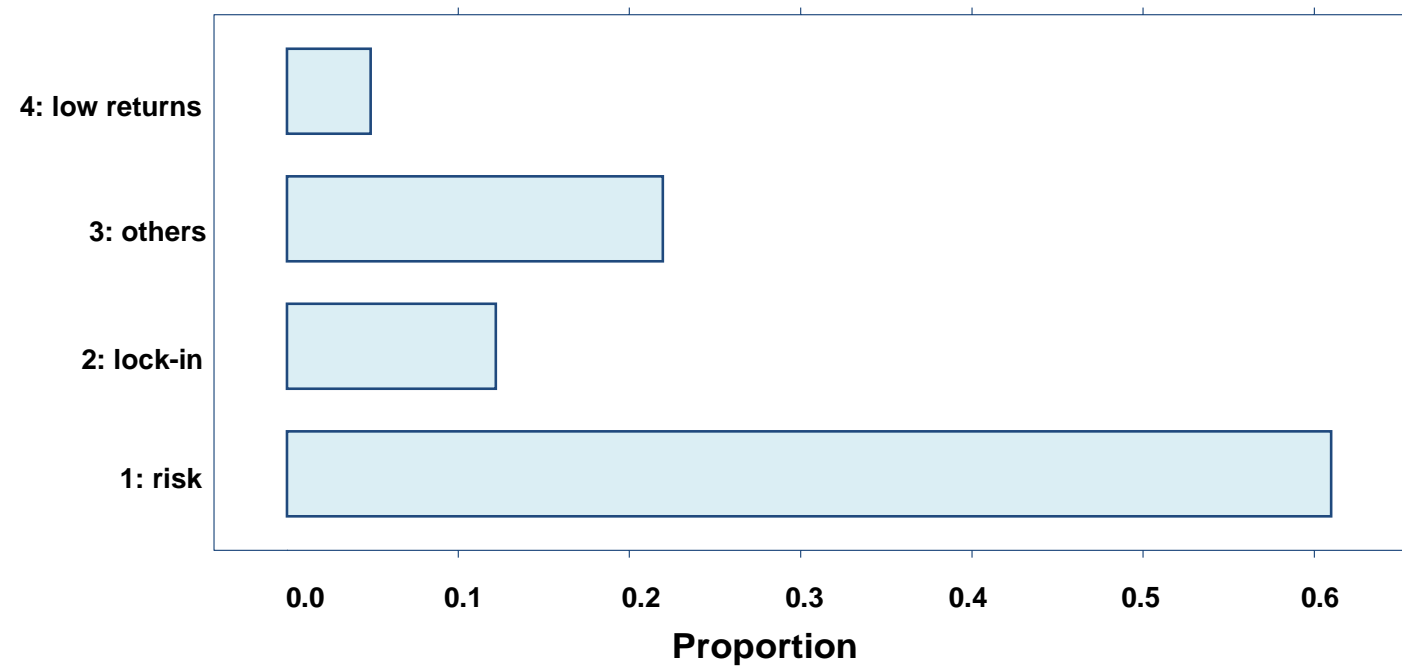

\footnotetext{
${ }^{16}$ It is important to remember here that while ULIPs are lower cost than mutual funds if held to term, more than half the products lapse before the completion of five years for the industry. In some firms the five year persistency number is less than 10 per cent. when products are discontinued midway the costs are very high for the investor.
} 


\subsection{What products get recommended?}

We have so far established that managers do not make inquiries about potential customers, and are not just distributors of products but actively provide advice. We, therefore, turn to the actual recommendations made by the bank managers. These are presented in Table4.

Fixed deposits were the most recommended product, followed by insurance and mutual funds. This is despite the fact that almost half our audits specifically asked for a mutual fund product. When auditors asked for any tax-saving product, mutual funds were recommended 2 percent of the time, while fixed deposits and insurance were recommended 53 and 36 percent of the time respectively.

\section{Table 4: Product recommendations}

This table describes the percentage of recommendations made by the bank managers. The numbers in the brackets indicate the standard deviations.

\begin{tabular}{lrrrr}
\multicolumn{5}{c}{ Products recommended (\%) } \\
\hline & Fixed deposit & Insurance & Mutual funds & Others \\
\hline Recommendation & 51 & 35 & 8 & 6 \\
& $(50)$ & $(48)$ & $(27)$ & $(23)$ \\
Asked for ELSS & 51 & 33 & 12 & 4 \\
Asked for a tax saving & $(50)$ & $(47)$ & $(32)$ & $(20)$ \\
instrument & 53 & 36 & 2 & 8 \\
& & & & $(15)$ \\
\hline
\end{tabular}

It is possible that bank managers have customer interest in mind, and the recommendations made by them are the most suitable product for the customer. But our observations show that the managers did not spend time to understand the personal situation of the auditor negating the possibility that the managers were actually working in customer interest to steer them away from a mutual fund. Also, if this were so, the manager should have followed it up with disclosures on what the most important product features were. This is especially so because as per the regulatory regime in India, the sale of any financial product should be accompanied by managers disclosing material product features which play an important role in the decision to purchase the product.

\subsection{Are recommendations accompanied by disclosures?}

We evaluate the disclosures made by the manager when making each product recommendation. Table 5 presents the results on disclosures made. Columns (1), (2) and (3) relate to disclosures made in the first round of the survey, whereas columns (4), (5) and (6) show the disclosures in the second round. As described earlier, in the first round, our auditors only noted the product features that were disclosed to them. 
We find that voluntary disclosures concentrated around returns and guarantees. The bank FD return was disclosed 6 percent of the time, while this number is 39 percent for insurance and 93 percent for mutual funds. The absurdly low 6 percent disclosure number for bank FDs might be explained by the presence of large posters in all bank branches stating the current FD return in bold across various time periods.

Almost all the auditors who were suggested a mutual fund product were disclosed their past returns and less than half for the insurance product is consistent with the actual returns data that shows ELSS giving a better average return as compared to an insurance product. Clearly the bank managers are talking up the best feature of the product, or the feature that they think matters to the customer. This insight is confirmed when we look at the data on guarantees. Ninety-five percent of auditors who were suggested a bank FD were disclosed the guaranteed nature of the product and almost three quarters of those who were suggested an insurance policy were told that it carries a guarantee. Just 7 percent of those who pitched the market-linked ELSS spoke about a guarantee.

Thus, regardless of the product recommended, when auditors did not ask for information, few disclosures were made. Almost no disclosures were made on the costs of the product and lock-in. This is consistent with Gine, Cuellar, and Mazer (2014) who find that staff voluntarily almost never provide information on avoidable fees, especially to uninformed auditors.

The story gets interesting when we move to analysing the Round 2 data. In round 2 auditors are actively asking questions about product features. Ninety-three percent of bank managers disclose returns for bank FDs. Ninety-eight percent disclose insurance returns and 93 percent disclose mutual fund returns. Clearly this is one feature that bank managers seem to be happy to disclose.

The story gets a little complicated when we look at how they behave when it comes to guarantees. Almost all of them answer the question for bank deposits and 27 percent disclose the information for ELSS. For the insurance product, however, just 40 percent disclose information about guarantees when asked for the insurance product. In Round 1, when no information was asked or the auditors seemed not to know what to ask bank managers gave information about guarantees 73 percent of the times. But when faced with a seemingly knowledgeable customer, the information on guarantees in an insurance product falls to almost half. One possible explanation of the guarantee disclosure dropping from 73 to 40 percent could be that managers expect that a more informed customer would know that market linked and participating plans do not have a guarantee, and hence were evading the question.

Bank managers did not answer the question on FD costs as just three percent of the auditors got a reply when they asked what the cost of an FD was. Bank managers answered the cost question 60 percent of the time for both insurance and ELSS. The willingness to answer the question on lock-in, or the period of time for which the investment is not liquid, is high - 90 percent of the bank managers answered this for the bank FD and insurance and 87 percent answered this for ELSS. Bank managers seemed happy to answer the costs of early exit question as well, with 89 percent answering for both bank FD and insurance and 73 
percent answering for the ELSS product. Every bank manager audited gave an answer to the optimal holding period question.

\section{Table 5: Percentage of disclosures made}

Columns (1), (2) and (3) relate to disclosures made in the first round of the survey, whereas columns (4), (5) and (6) show the disclosures in the second round. In the first round, our auditors only noted the product features that were disclosed to them. The NA indicates that these features were not specifically part of the first survey. In the second round, they were trained to ask for information on product features. For example, in round 1, when a fixed deposit was recommended, returns were voluntarily disclosed 6 percent of the time. In round 2 , when a fixed deposit was recommended, returns were disclosed 93 percent of the time. The numbers in the brackets indicate the standard deviations.

\begin{tabular}{|c|c|c|c|c|c|c|}
\hline & \multicolumn{3}{|c|}{ Round I } & \multicolumn{3}{|c|}{ Round II } \\
\hline & & (2) & (3) & (4) & (5) & (6) \\
\hline & $\begin{array}{r}\text { Fixed } \\
\text { Deposi }\end{array}$ & Insurance & $\begin{array}{r}\text { Mutual } \\
\text { Fund }\end{array}$ & $\begin{array}{r}\text { Fixed } \\
\text { Deposit }\end{array}$ & Insurance & $\begin{array}{r}\text { Mutual } \\
\text { Fund }\end{array}$ \\
\hline Returns & $\begin{array}{r}6 \\
632\end{array}$ & $\begin{array}{r}39 \\
(49)\end{array}$ & 93 & $\begin{array}{r}93 \\
95\end{array}$ & 99 & 93 \\
\hline Guarantees & $\begin{array}{r}(23) \\
95\end{array}$ & (49) & $\begin{array}{r}(26) \\
7\end{array}$ & $\begin{array}{r}(25) \\
97\end{array}$ & $\begin{array}{r}(10) \\
40\end{array}$ & $\begin{array}{r}(26) \\
27\end{array}$ \\
\hline 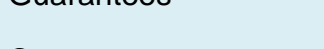 & (21) & (45) & (26) & (16) & (49) & (46) \\
\hline Costs & 0 & 0 & 0 & 3 & 60 & 60 \\
\hline & (0) & (0) & (0) & (16) & (49) & (51) \\
\hline Lock-in & $\begin{array}{r}0.8 \\
(0.8)\end{array}$ & 0 & 0 & 90 & 90 & 87 \\
\hline Charges on early exit & NA & NA & NA & 89 & 89 & 73 \\
\hline \multirow{3}{*}{ Optimal holding period } & \multirow{3}{*}{ NA } & \multirow{3}{*}{ NA } & \multirow{3}{*}{ NA } & (31) & (30) & (46) \\
\hline & & & & 100 & 100 & 100 \\
\hline & & & & (0) & (0) & (0) \\
\hline
\end{tabular}

\subsection{Are the disclosures correct?}

Our audits show that when asked, bank managers respond with information on disclosures. We test whether these disclosures are accurate. We evaluated the disclosures made on every product recommendation with the actual features from official product brochures. In some cases, bank managers respond to direct questions on costs or exits by saying, "as applicable". We classify this as an incorrect disclosure as an honest answer should have been that the bank manager does not know but will find out. The response of "as applicable" is vague enough to obfuscate the true costs. The percentage of incorrect disclosures is presented in Table 6 .

\subsubsection{Returns}

Returns was the most easily answered question. Disclosures on returns were less likely to be vague, and more likely to be a specific number. However, the returns disclosed were mostly incorrect.

FDs were the most correctly disclosed product. Only 35 percent of the returns 
disclosures were incorrect. However, in the case of a fixed deposit, where there is no ambiguity on returns, this number seems large. One possible explanation for this is that bank managers have not updated themselves to the change in interest rates on these products. Interest rates for fixed deposits used to be in the range of 8.25 to 8.75 percent till March 2015, but the softer interest rate regime in the FY 2015-2016 has seen rates drop to between and 8 percent during the period of the study. From the responses of bank managers, it does seem that they were mentally bench-marked to the earlier higher rate regime.

Table 6: Percentage of incorrect disclosures

The table shows the percentage of incorrect disclosures on product features in the second round of the study, when auditors specifically asked for information on product features. For example, 35 percent of returns disclosures on a fixed deposit were incorrect. The numbers in the brackets indicate the standard deviations.

\begin{tabular}{lccc} 
& Fixed Deposit & Insurance & Mutual Fund \\
\hline Returns & & & 86 \\
Guarantees & 35 & 99 & $(36)$ \\
Costs & $(48)$ & $(11)$ & 36 \\
& 2 & 34 & $(49)$ \\
Lock-in & $(17)$ & $(47)$ & $(36)$ \\
Optimal holding period & 4 & 100 & 50 \\
& $(20)$ & $(0)$ & $(52)$ \\
& 7 & 36 & 86 \\
\hline
\end{tabular}

Of all the insurance disclosures on returns, 99 percent did not show the correct returns. On looking at individual audits we discovered that there were three misrepresentations made.

- $\quad$ First, when the bank recommended guaranteed insurance products, the returns projections were in the range of 11-15 percent. This is a gross exaggeration because the guaranteed insurance plans typically return between 3-6 percent CAGR. Part of the problem is that the brochures themselves do not state the returns number upfront, or if a returns number is presented it is as a percent of sum assured and not the investment. The advisor has to look at the payouts and arrive at this number. The advisors do not seem to be making this effort.

- $\quad$ Second, when managers recommended the linked insurance products, returns were still overstated. We looked at each return indication and then looked at the actual return over the past years ( $3,5,7$ and since inception returns), and found that in just 2 percent of the cases, returns indicated matched the past returns on any of the above time periods.

- $\quad$ Third, when a market-linked insurance plan was recommended, in many cases it was represented as a plan with a guarantee, which is not only incorrect but skews the investor's mind towards something she is looking for, and familiar as well as comfortable with - a guaranteed assured return. 
Returns disclosures on mutual fund recommendations did slightly better than insurance recommendations, with 86 percent being incorrect. In all these cases the returns were overstated. We checked the past returns from inception and over a 5, 7 and 10 period to check the past performance. We found that managers were looking at just the past year returns, which were very high, as compared to the return history since inception to make the product look better.

We thus find that returns were over-stated in all three products. The least incorrect disclosures were in products that earn no commission, the most in insurance that have high front commissions. The return projections rose with the quantum of commission in the product across the three product categories. For instance, the discrepancy between projected and actual returns was about 1 percentage point in the case of fixed deposits, but was almost 10 percentage points in the case of traditional insurance plans.

\subsubsection{Guarantees}

In the case of guarantees as well, we have taken an answer "as applicable" or "as per terms" as an incorrect reply as it is likely that the bank manager is giving a vague reply to a direct question to either deliberately obfuscate or hide his own financial illiteracy.

The information on guarantees was most accurate w.r.t bank FDs. Just two percent of the bankers gave incorrect information to this question. In the case of insurance, the recommended product may be a traditional product (non-participating) where the return is guaranteed, or a unit-linked or a (participating) endowment plan, where the return is market linked (or linked to profits of the company). We classified each of the insurance recommendation as a traditional or a unit-linked product, and also checked the brochure of the product online to confirm if the product did in fact carry a guarantee. We found that in 30 percent of the cases, market-linked insurance products were disclosed as having a guaranteed return. 36 percent of the managers indicated that the ELSS being sold carried a guaranteed return.

\subsubsection{Costs}

The responses on costs were less clear than that of returns or guarantees. As described earlier, we classify responses in the form of statements such as "as applicable", as incorrect. We found that the more complicated the cost structure, the greater the proportion of incorrect disclosures made by managers.

While 4 percent misrepresentation of costs on fixed deposits seems low, for a fixed return product with no entry, management and exit costs, there should have been no incorrect disclosures. We, therefore, looked at each audit report and found that in these 4 percent of the cases, the bank manager had said costs were "as applicable" and not "zero", which in the strictest sense, is not a correct disclosure as it indicates that managers are themselves not aware of the features of the product, or do not want to take the effort to explain the complexity of the cost structures. 
All the cost disclosures on insurance products were incorrect or incomplete. Some managers said that there was no cost attached to the product. Some got the front load right but ignored the ongoing costs of fund management and that of mortality. None of the managers spoke about the costs of an early exit from a closed end 10-15 year product. The more complicated the cost structure of the product, the less able the manager was to communicate costs. We saw attempts in the qualitative study of some banks trying to explain costs over the lifetime of the product, but these were limited to the front load on the product and not on the overall costs that the investor would face.

In the case of a mutual fund product recommendation, 85 percent of the managers misrepresented costs by understating them. A cost number of zero was given in many cases. It is true that there are no entry loads in mutual funds in India and all costs sit under the "expense ratio" head. Ideally the manager should have communicated that number when asked on costs.

\subsubsection{Lock-in and holding period}

The banks got the lock-in question right almost 93 percent of the times when recommending a fixed deposit. However, the optimal holding period was wrong 12 percent of the times. Either the question was ignored or a holding period longer than the lock-in was given. Insurance disclosures did a little better on lock-in periods compared to costs with only 36 percent being incorrect. More than 60 percent of managers recommending insurance, however, failed to disclose the optimal holding period correctly. In fact, several managers misrepresented the lock-in as the optimal holding period. Whether this was deliberate or the managers themselves did not know, is unclear.

The lock-in disclosure on mutual funds saw 50 percent of the managers misrepresenting the three year lock-in. Similarly, 86 percent of the managers gave an incorrect answer for the optimal holding period of a mutual fund. Equity is not a short-term product and though the lockin is for three years, an ELSS product needs to be held for at least 5-7 years to get the benefit of long-term equity return.

Overall, the lock-in period did not see many incorrect disclosures. However, there seemed to be confusion in both mutual fund and insurance sales between lock in and optimal holding period. Sellers seemed to know about the lock-in period, but assumed that the lock-in was the optimal holding period.

\subsection{What might be driving these recommendations?}

We have seen so far that fixed deposits and insurance are the most recommended products, and recommendations are not followed by disclosures. When disclosures are made, they are largely incorrect or incomplete. We now evaluate the drivers of the recommendations. 


\subsubsection{Bank manager paternalism}

One could argue that bank managers did actually have customer interest in mind, and recommended the products that they thought were the best for them. Let us look at the deals that were available to the auditor. By our simple calculations, Rs 100,000 invested for 10 years would grow to:

- Rs 196,715 in an FD that gives $7 \%$

- Rs 148,024 in a traditional insurance plan that returns $4 \%$

- Rs 455,026 in a unit linked insurance plan that returns $16.36 \%{ }^{17}$

- Rs 487,712 in an ELSS that returns $17.17 \%$

A public sector bank customer is only sold plans that give about 7 percent return. This return is guaranteed and hence perhaps more valuable than what the auditor would have earned through an ELSS. One could argue that the bank manager was overly concerned about the auditors taking market risk and hence, in the interest of the customer, recommended a fixed deposit product. However, in a high inflationary environment the real rate of return on a fixed deposit is very low, and in no conversation did we see the man- ager warn the auditor about this risk. Also, in no conversation did the auditor present the choices to the customer, and in fact, when the customer specifically asked for the ELSS, directed him to other products.

One could argue that insurance was the right product to recommend for the purpose of saving tax, and whenever such a product was available (owing to the tie-up), it was recommended. Private sector bank customers are sold traditional insurance plans that give a return of between 3-6 percent or unit linked plans that have given a return of less than 12 percent post deduction of costs. Let us look at both.

Consider an Rs 25,000 investment in a standard 15 year endowment policy that gives a life cover of Rs 2.5 lakh and an average annual tax free return of 4 percent. If the investor outlives the policy, he gets a corpus of Rs5 lakh. This same Rs 25,000 can instead be split into two. One part buys a term policy that provides a cover of Rs 2.5 lakh and costs Rs 750 . The remainder Rs 24,250 could be invested in a term deposit that current provides a little over 8 percent. ${ }^{18}$ If the investor outlives this policy, he gets Rs 6.95 lakh, as compared to the Rs 5 lakh. If insurance was the right product for the customer, the bank manager should have sold a term insurance product, and advised the customer to invest the remaining in a term deposit.

Consider the ULIP. This is a market linked product that has provided lower returns than an ELSS. If the customer is to take market risk, then again, the customer could have been directed to a term insurance product, and a ELSS product. It is, thus, difficult to conceive of a situation where a bundled insurance plan dominates any other product in the array of available tax-saving products (Anagol, Cole, and Sarkar, 2012), especially when disclosures have not been forthcoming or have been inaccurate. In addition, since the bank manager did not try

\footnotetext{
${ }^{17}$ Returns are lower since ULIP NAV does not include all the product costs.

${ }^{18}$ It is possible that the fixed deposit rate could fall, but more likely that a fixed deposit will have some link with current rate of inflation.
} 
and ascertain the personal and financial situation of the client or his future plans, it is a little difficult to believe in the paternalistic bank manager argument.

\subsubsection{Incentives}

If it is difficult to make the case for bank manager paternalism, perhaps the story likes in the incentive structure facing managers. In the Indian setting, FDs are the cheapest product, while insurance plans are the most expensive, with mutual funds somewhere in between. The stark difference in the remuneration to agents through upfront commissions between mutual funds and insurance is also evident in Table 1 described in Section 2.2. When remuneration is linked to commissions, it is likely that high-fee paying products will get sold.

Table 7 presents the results from a regression of the high commission recommendation on the request made, the amount to be invested, and the characteristics of the bank i.e. whether it had a tie-up to distribute third party products, and whether it was a public sector bank. The regression includes month and time (i.e. morning or the afternoon) of audit, zone and auditor fixed effects. These ensure that any variation in time and zone in which the audit was conducted, as well as the characteristics of the auditor are accounted for.

When managers ask about the overall goals, they are 16 percent more likely to recommend the high fee generating product. We know that the overall goal of our auditors was tax-saving (by our design). This information is unlikely to provide any other details to the bank manager, and in fact the managers also did not follow this question asking for more details. This suggests that this was a perfunctory task that managers performed. It might also suggest that such conversations facilitate the sale of high commission products by making the customer feel that the sale is in his interest.

The most important variable that drives the high commission's recommendation is whether the bank has a tie-up to distribute third party products. Banks with tie-ups are 69 percent more likely to recommend an insurance product relative to banks without tie-ups. This suggests that when banks have tie-ups with third party distributors, remuneration policies do play a role in their recommendations. Managers are incentivised to offer the more expensive ones (Anagol, Cole, and Sarkar, 2012; Gine, Cuellar, and Mazer, 2014).

What is surprising is that the high commission recommendation is lower for public sector bank tie-ups. It is highly unlikely that managers in public sector banks do not know of the insurance products once the bank has an official tie-up with an insurance company. When we investigated further, we found that remuneration in public sector banks is not directly linked to sales volumes, but is driven by salary "scales". Only the senior management positions get some variable pay, which is also determined by a set formula. This might be a potential explanation for why public sector bank managers are less likely to sell the high commission product as their incentives do not require them to achieve high sales targets.

There is another difference in the incentive structure of public and private sector banks that is worth noting. Private banks are tightly focused on the NIM and profits. Public sector banks, on the other hand, focus on growing their deposits. The incentive structures in the two 
types of banks reflect this focus. A private sector bank manager is incentivised to sell the highest commission product because of his variable pay being tied to sales. A public sector bank manager is incentivised to sell fixed deposits because his promotions are driven by deposit mobilisation targets. In either case, we find that managers are responding to their own incentives. Unless customer well-being is an explicit incentive, it is unlikely that customer interest will be at the forefront.

Table 7: Regression: Determinants of the high Commission Recommendation

The table presents the results from a linear regression. The dependent variable is 1 if a high commissions product (insurance) was recommended. The base category for the product request is the mutual fund request, for the investment amount is Rs 25,000 and for bank tie-up is no tie-up. The regression includes month and time (i.e. morning or the afternoon) of audit, zone and auditor fixed effects. These ensure that any variation in time and zone in which the audit was conducted, as well as the characteristics of the auditor are accounted for.

Asked: some tax

Dependent variable:

High Commissions Product

Investment amount: Rs 100,000

0.012

(0.040)

0.039

$(0.037)$

Asked overall goals

$0.161^{* * *}$

$(0.048)$

Asked if have other tax investment

$-0.049$

(0.049)

$0.699 * * *$

Bank tie-up

$(0.070)$

Bank tie-up*Public sector bank

$-0.557$

$0.049)$

Gender of bank manager: MALE

0.027

(0.047)

0.037

Month of audit: July

$(0.142)$

$-0.069$

Constant

(0.111)

$\mathrm{R}^{2}$

0.496

F Statistic

Auditor FE

$18.498^{* * *}(\mathrm{df}=19 ; 357)$

YES

Zone FE

YES

Time FE

YES

$N$

${ }^{*} p<0.1 ;{ }^{* *} p<0.05 ;{ }^{* * *} \mathrm{p}<0.01$

\subsection{What drives the disclosures?}

As we saw in Table 5, recommendations were rarely followed by disclosures. In this section we evaluate what are the drivers of disclosures. Table 8 shows the results from a regression of the characteristics that determine these disclosures. The dependent variable is 1 , if the bank manager made a disclosure and 0 otherwise.

When auditors ask for any tax-saving product, they are less likely to be given information on returns and costs relative to those who ask for a specific product. This is consistent with 
the idea that customers, who seem to have an idea about investment products, get better service (Anagol, Cole, and Sarkar, 2012). Being informed, that is making a specific product request, does not make any difference in disclosures on guarantees, lock- in or charges on early exit. This suggests that the more complicated features of a product are rarely disclosed.

Public sector banks are more likely than private sector banks to give information on all product features except returns and costs. This may be driven by the fact that public sector banks are more likely to recommend fixed deposits, and costs are not a salient feature of fixed deposits. They may also expect customers to know about fixed deposit returns. The fixed deposit is also a simple product, easy for bank managers themselves to understand, and hence explain to their customers. Since private sector banks are largely recommending the more complicated product (i.e. insurance), they are less likely to make disclosures on product features than public sector banks. This also suggests the possibility that bank managers themselves are ignorant about complex product features, and hence are unable to communicate to their customers.

Overall, our results suggest that disclosures are rarely voluntarily made, especially on complex attributes such as costs and lock-in. Very often, customers do not even anticipate the kinds of costs that may be embedded in a product, or the rules around a lock-in. If these features are not in their frame of reference, they are unlikely to ask for them, and even less likely to be told about them. This points to the difficulty in the use of disclosures in achieving consumer protection, both when customers have limited understanding of the relevance of product characteristics, and distributors themselves are either ignorant or influenced by incentives.

\section{Table 8: Regressions: Disclosures}

This table presents the results from a regression of the characteristics that determine these disclosures. The dependent variable is 1 if the bank manager made a disclosure and 0 otherwise. The excluded cate- gory for asked for some tax saving instrument, is asked for ELSS. The excluded category for investment amount is Rs 25,000. The excluded category for bank is a private sector bank. The excluded category for gender of bank manager is female. The excluded category for month of audit is March.

Dependent variable:

\begin{tabular}{lccccc}
\hline & $\begin{array}{c}\text { Returns } \\
(\mathbf{1})\end{array}$ & $\begin{array}{c}\text { Guarantees } \\
(\mathbf{2})\end{array}$ & $\begin{array}{c}\text { Costs } \\
\mathbf{( 3 )}\end{array}$ & $\begin{array}{c}\text { Lock-in } \\
\mathbf{( 4 )}\end{array}$ & $\begin{array}{c}\text { Charges on } \\
\text { early exit } \\
\mathbf{( 5 )}\end{array}$ \\
\hline Asked: & $-0.106 * * *$ & 0.024 & $-0.059 *$ & -0.003 & 0.033 \\
some tax & $(0.030)$ & $(0.039)$ & $(0.033)$ & $(0.040)$ & $(0.041)$ \\
Investment amount: & $0.050 *$ & 0.015 & -0.019 & 0.044 & 0.012 \\
Rs 100,000 & $(0.030)$ & $(0.039)$ & $(0.033)$ & $(0.039)$ & $(0.040)$ \\
Public sector bank & $-0.110 * * *$ & $0.471 * * *$ & $-0.268 * * *$ & $0.071 *$ & $0.085 * *$ \\
Bank manager: MALE & $(0.033)$ & $(0.044)$ & $(0.037)$ & $(0.041)$ & $(0.042)$ \\
& -0.046 & -0.026 & $0.078 *$ & -0.052 & -0.049 \\
Month of audit: July & $(0.038)$ & $(0.050)$ & $(0.042)$ & $(0.041)$ & $(0.042)$ \\
& $0.546 * * *$ & -0.094 & 0.117 & & \\
Constant & $(0.113)$ & $(0.148)$ & $(0.125)$ & & $0.984 * * *$
\end{tabular}




\begin{tabular}{lccccc} 
& $(0.085)$ & $(0.112)$ & $(0.094)$ & $(0.066)$ & $(0.067)$ \\
Observations & 378 & 378 & 192 & 192 & 192 \\
R2 & 0.683 & 0.326 & 0.320 & 0.187 & 0.269 \\
F Statistic & $48.651^{* * *}$ & $10.902^{* * *}$ & $11.986^{* * *}$ & $3.426^{* * *}$ & $5.476^{* * *}$ \\
Time FE & YES & YES & YES & YES & YES \\
Zone FE & YES & YES & YES & YES & YES \\
Auditor FE & YES & YES & YES & YES & YES \\
\hline
\end{tabular}

Note:

${ }^{*} \mathrm{p}<0.1 ;{ }^{* *} \mathrm{p}<0.05 ; * * * \mathrm{p}<0.01$

\section{Conclusion}

This paper conducts an audit study of 400 bank branches in the city of Delhi, India. We find that in private sector banks with high sales incentives, the high commission product is recommended. In public sector banks, where there are deposit mobilisation targets, fixed deposits are recommended.

This paper is also one of the first papers to provide evidence on the process of disclosures of product features, and the veracity of the disclosures made. It shows that the more complex features of a product, such as costs are very rarely voluntarily disclosed. When specifically requested, information provided is inaccurate or incomplete.

Our results point to the difficulties in the use of disclosures for achieving better consumer outcomes. Even if disclosures are made mandatory on product brochures, it is unlikely that they get conveyed to the customer in the correct manner. Anecdotally, the process of sale is as follows. The bank manager verbally describes the product or scribbles the product design on an unsigned blank paper. Customers rarely understand know enough about costs, returns and the impact of an early exit to ask or to evaluate what has told to them, and buy into the contract. The regulators have taken the view that since the customer has signed on the documents, the customer is responsible for the purchase. The problem is made worse due to the lack of fixing responsibility on the sales channel for mis-sold products. Unless there is a mechanism of enforcement, a disclosure policy is unlikely to help achieve better outcomes. Our research illustrates the importance of making disclosures machine readable so that third party league tables can be created, giving consumers a yardstick to measure the firm and products.

Regulators play a dual role in India - that of market development and regulation. This dual role has resulted in a greater focus on making financial companies viable and profitable rather than ensuring financial well-being of customers. For instance, regulators speak of market penetration and not financial well-being. The industry size is measured by metrics that give us the size of the firms and not by metrics that reflect product usage. While the concern about the collision between hard-driving financial firms and the average investor is rising, it has been over-ridden with the argument that the problems are minor, sporadic and over-stated by a sensationalist media. This paper provides evidence that mis-selling is real. Our study also raises questions on the suitability of banks as a vendor of third party financial products in an emerging economy with weak regulation and enforcement. 
Episodes of mis-selling have led countries such as the UK, EU and Australia towards a complete overhaul of their distribution policies. ${ }^{19}$ In an emerging market such as India, where customers have a lower exposure to knowledge about choices in financial contracts, and where there is lower competition among financial firms, the problems of mis-sales can be exacerbated. In such a context, subsequent breakdowns in customer protection impose large costs, not just in terms of losses to customers, but also in leading to a general mistrust of finance and a persistent low reach and development of financial markets. This can ultimately have a bearing on the productive use of capital.

${ }^{19}$ For more details, see the Retail Distribution Review in the UK, the group on Packaged Retail Investment Products (PRIPs) under the Markets in Financial Instruments Directive (MiFID) Implementing Directive in the EU, and the Future of Financial Advice reforms in Australia. 


\section{References}

AMFI. (2015). Folio and Ticket Size. Retrieved from: https://goo.gl/5WNFSN.

Anagol, Santosh, Shawn Cole, and Shayak Sarkar. (2012). Understanding the Incentives of Commissions Motivated Agents: Theory and Evidence from the Indian Life Insurance Market. Working Paper 12-055, Harvard Business School.

Anagol, Santosh and Hugh Hoikwang Kim. (2012). The Impact of Shrouded Fees: Evidence from a Natural Experiment in the Indian Mutual Funds Market, in American Economic Review 102(1): 576-93. Retrieved from: http://EconPapers.repec.org/RePEc: aea:aecrev:v:102:y:2012:i:1:p:576-93.

-Vijaya B. Marisetty, et al. (2014). On the Impact of Regulating Commissions: Evidence from the Indian Mutual Funds Market, in World Bank Economic Review (forthcoming).

Balaji, Kavya and Deepti Bhaskaran. (2015). Why banks resort to mis-selling. Livemint, 22 December 2015. Accessed at: http://goo.gl/ktzmi1.

Barbora, Lisa Pallavi and Viviana Vishwanathan. (2016). Tough to separate sales from advisory. LiveMint, 28 April 2016. Retrieved from: http://goo.gl/RJrwJ2.

Basu, Debashis. (2015). Regulators versus customers. Business Standard, 25 January 2015. Retrieved from: http://goo.gl/UvGa0g.

Beshears, John et al. (2009). How Does Simplified Disclosure Affect Individuals' Mutual Fund Choices? Working Paper 14859. NBER.

Beyer, Max, David de Meza, and Diane Reyniers. (2013). Do financial advisor commissions distort client choice?, Economics Letters 119(2): 117-119.

Bhaskaran, Deepti. (2015). There's more to tax-saving products. Livemint, 25 January.

Retrieved from: http://goo.gl/W9lseU.

Bordo, Michael D. and Peter L. Rousseau. (2012). Historical evidence on the finance- tradegrowth nexus, in Journal of Banking and Finance 36(4): 1236-43.

Campbell et al. (2011). Consumer Financial Protection, in Journal of Economic Perspectives, 25(1): 91-114.

Das, Jishnu and Jeffrey Hammer. (2007). Money for nothing: The dire straits of medical practice in Delhi, India, in Journal of Development Economics 83:1-36.

Datta-Ray, Sunanda K. 2015. A ride you can't bank on. Business Standard, 10 July. Retrieved from: http://goo.gl/oVrwOi.

DEA. (2015). Report of the Committee to recommend measures for curbing mis-selling and rationalising distribution incentives in financial products. Committee headed by Sumit Bose. Department of Economic Affairs, Ministry of Finance, Government of India. Retrieved from: http://goo.gl/B1N05Y.

DFS. (2014). Pradhan Mantri Jan Dhan Yojana (PMJDY). Department of Financial Services, Government of India. Retrieved from: http://www.pmjdy.gov.in/about. .(2015a). Atal Pension Yojana. Retrieved from: 
http://jansuraksha.gov.in/Default.aspx.

.(2015b). Pradhan Mantri Jeevan Jyoti Bima Yojana (PMJJBY). Department of

Financial Services, Government of India. Retrieved from:

http://jansuraksha.gov.in/Default. aspx.

-(2015c). Pradhan Mantri Suraksha Bima Yojana. Retrieved from:

http://jansuraksha.gov.in/ Default.aspx.

Duarte, Fabian and Justine S. Hastings. (2012). Fettered Consumers and Sophisticated Firms: Evidence from Mexico's Privatized Social Security Market. Working Paper 18582. NBER.

Fishman, Michael $\mathrm{J}$ and Kathleen M Hagerty. (2003). Mandatory versus voluntary disclosure in markets with informed and uninformed customers, in Journal of Law, Economics, and Organization 19(1): 45-63.

Gabaix, Xavier and David Laibson. (2006). Shrouded Attributes, Consumer Myopia, and Information Suppression in Competitive Markets, in The Quarterly Journal of Economics.

Gine, Xavier, Cristina Martinez Cuellar, and Rafael Keenan Mazer. (2014). Financial (DisInformation: Evidence from an Audit Study in Mexico). Policy Research Working Paper WPS6902. The World Bank.

Guiso, Luigi, Paola Sapienza, and Luigi Zingales. (2008). Trusting the Stock Market, in The Journal of Finance 63(6): 2557-2600.

Halan, Monika. (2015). SEBI gives RBI a chance to clean up mis-selling by banks. Livemint, 14 September 2015. Retrieved from: http://goo.gl/S6Pbbx.

Renuka Sane, and Susan Thomas. (2014). "The case of the missing billions: estimating losses to customers due to mis-sold life insurance policies, in Journal of Economic Policy Reform 17(4).

Heidhues, Paul, Botond Koszegi, and Takeshi Murooka. (2014). Inferior Products and Profitable Deception. Working Paper. Eur. Sch. Manag. Technol., Berlin.

IRDA. (2002). Insurance Regulatory and Development Authority (Protection of Policyholders' Interests) Regulations, 2002. Insurance Regulatory and Development Authority Notification, Ref: 1385 Gl 2002 ENG, 16th October 2002. Retrieved from: http : / / goo . $\mathrm{gl} / \mathrm{LNsWO1.}$

(2011). Report of the Committee on Bancassurance. Committee Report. Insurance Regulatory and Development Authority.

IRDAI. (2014). Annual Report.

IRDAI, (2016). Insurance Regulatory And Development Authority Of India (Payment Of Commission Or Remuneraton Or Reward To Insurance Agents And Insurance Intermediaries) Regulations, 2016. Exposure Draft. Retrieved from: http://goo.gl/xq2ZpS.

Joshi, Anurag and Arnav Pandya. (2003). Banks see an opportunity in third party distribution. Economic Times, 26 August 2003. Retrieved from: http://goo.gl/Q78NTW. 
Kozup, John, Elizabeth Howlett, and Michael Pagano. (2008). The Effects of Summary Information on Consumer Perceptions of Mutual Fund Characteristics, in The Journal of Consumer Affairs 42(1): 37-59.

Levine, Ross. (2005). Finance and Growth: Theory and Evidence, In Philippe Aghion and Steven N. Durlauf (Eds.) Handbook of Economic Growth, (pp. 865-934). Amsterdam: Elsevier.

Loewenstein, George, Daylian M. Cain, and Sunita Sah. (2011). The Limits of Transparency: Pitfalls and Potential of Disclosing Conflicts of Interest, in The American Economic Review, Papers and Proceedings of the One Hundred Twenty Third Annual Meeting OF THE AMERICAN ECONOMIC ASSOCIATION. 101.3.

Milgrom, Paul. (2008). What the seller won't tell you: Persuasion and disclosure in markets, in Journal of Economic Perspectives 22(2):115-131.

Mowl, Amy and Camille Boudot. (2014). Barriers to Basic Banking: Results from an Audit Study in South India. NSE Working Paper Series WP-2014-1. NSE-IFMR Financial Inclusion Research Initiative 2014-15.

Mullainathan, Sendhil, Markus Noeth, and Antoinette Schoar. (2012). The market for financial advice: An audit study. Working Paper 17929. NBER.

RBI. (2015). Master Circular - Para-banking Activities, RBI/2015-16/30, DBR.No.FSD.BC.19/24.01.0016. Retrieved from: http:// goo.gl/1c8bb1.

Saraswathy, M. (2015). Irdai tightens norms to check insurance mis-selling by banks. Business Standard, 21 July 2015. Retrieved from: http:// goo.gl/h8pfgU.

SEBI. (2014). Master Circular for Mutual Funds. Securities and Exchange Board of India, Circular: CIR/IMD/DF/18/2014, 1 October 2014. Retrieved from: http://goo.gl/md3Snw. Shaton, Maya O. (2014). The Display of Information and Household Investment Behavior. Job Market Paper. Retrieved from: http://home.uchicago.edu/mayashaton/JMP Maya Shaton.pdf: University of Chicago Booth School of Business.

White House. (2015). The Effects of Conflicted Investment Advice on Retirement Savings. Tech. rep. Executive Office of the President of the United States. 


\section{A The tax saving products}

Figure A.1: Tax saving products in India

\section{KNOW YOUR SECTION 80C PRODUCTS}

The various products products and their tax treatment.

Prouat"

Public Providest fund (PFF)

Encksyces' Prwitent Fund (EF)

Equity-liked Saings Scherme (ELSS)

Uile insurance penium

Natonal Srings Cortficate (NSO)

Sowr Crian Sarings Schame (SCSS)

Post effike fieod desosit and tank

floed deposit for fhe yers

Kational Pensibn Systen (UPSY

Rersha plus by insures

Proim glens by rutual findse:
Contritutise

2900-1.5lakh

125 of 215,000:12s of your salary

Usurlly minimun is 2500

Not mare than 106 of the sum ascured:

Vinimum ₹:00

21000-15 tak

Sinimum ₹100

₹6.000

NA

₹SO

\section{Tenc}

15 ysurs, Syear enterbors

Til restrenent

Lodin of 3 yoxs

Mrinum bokh5 yours"

5 yours and 10 yers

5 yeurs con be extented by 3 yars

5 yeurs

TI 60 vears

Ac spedified in policy brocture

Mrinum bokn 3 ytars
Rose of resum for Fas Tas beatment

s.70s Taxiree

s.m5 tax-free

Market-linted Taxtree

Varies acnoss plans":- Tax-free

850s (5-yex brm)

8.80500 -yartoem

$2.20 \%$ Interst is tarable

$850 \%$ (post of ice depist) Varies across banks

Markst-linted Tazble on maturity

Markst inined or dechled Up to 1/3rd materity can be byinsarer commuted ta-free

Marketinted Leng-term capial gains tased at $20.5 \%$ with indecation

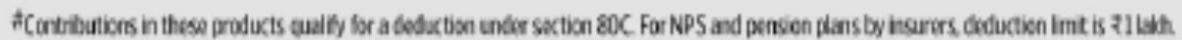

"Fou con centribse mare voluntarly and get the same rate of interest and tax terefits

"Requirenent to avail tar bencits

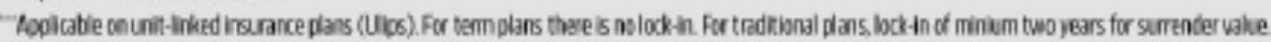

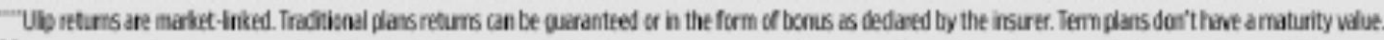

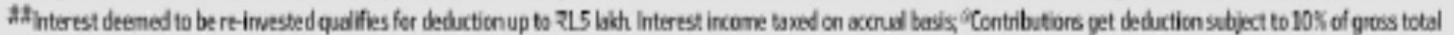
heore up to ₹1lakh

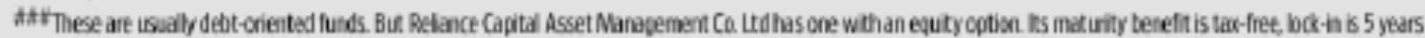

Source: Bhaskaran (2015) 


\section{B Tables}

Table B.1: Distribution by geography and ownership

\begin{tabular}{rlllll}
\hline & Centre & East & North & South & West \\
\hline Private (Number) & 20 & 19 & 23 & 51 & 44 \\
(Proportion) & 0.05 & 0.05 & 0.06 & 0.13 & 0.11 \\
Public (Number) & 27 & 42 & 15 & 71 & 95 \\
(Proportion) & 0.07 & 0.10 & 0.04 & 0.17 & 0.23 \\
\hline
\end{tabular}

Table B.2: Distribution across treatments

Public banks

Private banks

\begin{tabular}{lll|ll} 
& Rs 25,000 & Rs 100,000 & Rs 25,000 & Rs 100,000 \\
\hline ELSS & 75 & 54 & 30 & 47 \\
Some Tax & 66 & 53 & 30 & 43 \\
Total & 141 & 120 & 60 & 90 \\
\hline
\end{tabular}

Table B.3: Distribution of auditors across treatments

$\%$ of audits across treatments

\begin{tabular}{ccccc|cc} 
& $\begin{array}{r}\text { Rs 25,000 } \\
\text { ELSS }\end{array}$ & $\begin{array}{r}\text { Rs 25,000 } \\
\text { Tax }\end{array}$ & $\begin{array}{r}\text { Rs 100,000 } \\
\text { ELSS }\end{array}$ & $\begin{array}{r}\text { Rs 100,000 } \\
\text { Tax }\end{array}$ & Private & Public \\
\hline Auditor 1 & 4 & 3 & 4 & 3 & 3 & 11 \\
Auditor 2 & 2 & 1 & 2 & 2 & 2 & 6 \\
Auditor 3 & 9 & 8 & 9 & 9 & 15 & 19 \\
Auditor 4 & 4 & 4 & 3 & 5 & 4 & 12 \\
Auditor 5 & 2 & 2 & 3 & 2 & 5 & 4 \\
Auditor 6 & 2 & 3 & 2 & 2 & 7 & 3 \\
Auditor 7 & 3 & 3 & 2 & 2 & 3 & 8 \\
\hline
\end{tabular}


Table B.4: Comparing mutual fund and insurance costs

\begin{tabular}{|c|c|c|c|}
\hline Product & $\begin{array}{l}\quad \text { Front Loads } \\
35 \% \text { for companies older than } 10 \\
\text { years for }>12 \text { year term }\end{array}$ & Other costs & Overall cost \\
\hline Equity Funds & Nil & $\begin{array}{l}\text { Rs } 100 \text { for Investment }> \\
\text { Rs } 10,000 \text { Rs } 150 \text { for first } \\
\text { time investor }\end{array}$ & $3 \%$ \\
\hline Debt funds & Nil & $\begin{array}{l}\text { Rs } 100 \text { for investment }> \\
\text { Rs } 10,000 \text { Rs } 150 \text { for first } \\
\text { time investor }\end{array}$ & $2.75 \%$ \\
\hline \multicolumn{4}{|l|}{ Insurance } \\
\hline ULIPS & $\begin{array}{l}5-10 \% \text { industry standard and } \\
\text { decreasing scale for subsequent } \\
\text { years }\end{array}$ & $\begin{array}{l}\text { Administration, mortality, } \\
\text { fund management }\end{array}$ & $\begin{array}{c}\text { Reduction in } \\
\text { yield of max } \\
3 \%(2.25 \%) \\
\text { for policies < } \\
10 \text { years) }(> \\
10 \text { years }\end{array}$ \\
\hline Traditional & $\begin{array}{l}15 \% \text { of } 1^{\text {st }} \text { year premium for policy } \\
\text { terms of }<5 \text { years } \\
18-33 \% \text { of } 1^{\text {st }} \text { year premium for } \\
\text { policy terms of } 6-11 \text { years } \\
40 \% \text { of } 1^{\text {st }} \text { premium for }>12 \text { year } \\
\text { term }\end{array}$ & No cost cap & No cost cap \\
\hline
\end{tabular}


MORE IN THE SERIES

- Bhattacharya, R., 2016. "How

Does Supply Chain Distortion

Affect Food Inflation in India?"

WP No. 173 (August).

Monika Halan, is Consulting

Editor, Mint and Consultant with NIPFP

Email:

monikahalan@gmail.com

- Sapre, A., Sinha P., 2016. "Some

Areas of Concern about Indian

Manufacturing Sector GDP

Estimation", WP No. 172

(August)

Renuka Sane, is Visiting

Faculty at ISI, Delhi

Email: renukas@gmail.com

- Bhanumurthy, N.R., Prasad M.,

Jain R., 2016. "Public Expenditure,

Governance and Human

Development: A Case of Madhya

Pradesh", WP No. I7I (July)

National Institute of Public Finance and Policy,

18/2, Satsang Vihar Marg,

Special Institutional Area (Near JNU),

New Delhi 110067

Tel. No. 26569303, 26569780, 26569784

Fax: 91-11-26852548

www.nipfp.org.in 